\title{
TRADITIONAL USE AND CONSERVATION OF THE "CALAVERITA" LAELIA ANCEPS SUBSP. DAWSONII F. CHILAPENSIS SOTO-ARENAS AT CHILAPA GUERRERO MÉXICO
}

\author{
Victor M. Salazar-Rojas ${ }^{1,3}$, B. Edgar Herrera-Cabrera', \\ Alejandro Flores-Palacios ${ }^{2} \&$ Ignacio Ocampo-Fletes $^{1}$ \\ ${ }^{1}$ Colegio de Postgraduados en Ciencias Agrícolas - Campus Puebla, Programa en Estrategias para el Desarrollo \\ Agrícola Regional. Km. 125.5 Carr. Fed. Méx.-Pue. Col. La Libertad. Puebla, Puebla. CP 72130 México \\ ${ }^{2}$ CEAMISH Universidad Autónoma del Estado de Morelos Av. Universidad 1001 Cuernavaca, Morelos. \\ CP 62209 México \\ ${ }^{2}$ Author for correspondence: adnbic@gmail.com
}

KEY WORDS: traditional use, backyards, women, use value, morphologic variation

Mexico lodges a heritage of traditional knowledge on use, management and conservation of a great variety of genetic resources tie to its culture and idiosyncrasy (Davis et al. 1994; Toledo 1991). That heritage is protected in the memory of the indigenous and rural villages of the country, which by means of the daily practice and oral transmission of their customs, have allowed several species to survive, among them some orchids of the genus Laelia (Halbinger and Soto 1997, Toledo 1991).

Considering that Laelia anceps subsp. dawsonii f. chilapensis is one of the most beautiful mexican orchids, and that around it exists an experience of traditional appropriation in some indigenous and rural communities, reason why it is well-known locally like "calaverita", this work had as objective to study the local strategy of use and conservation of the Calaverita (Laelia anceps subsp. dawsonii f. chilapensis) and its floral morphological variation in the region of Chilapa Guerrero, Mexico.

The study was carried out through methodologies of qualitative and quantitative order: a) Oral history for reconstruction of the context in which the traditional use system develops and the collective memory that validates the practices (Of Garay 1994). For this point they were considered two women of 84 and 76 years old as key informants, both women were determined and recognized by the own community as authorities on the calaverita knowledge. b) Lip morphometric analysis, to represent variation within the clones of the chilapensis form. It included the dissec- tion and placement below a glass slide for drawing of 145 lip samples, measurement of lengths of 32 lines in a truss network drawn up to the interior of lip, logarithmic transformation of the measurements to consider the proportion, the generation of a matrix of correlations among the 32 variables, and a Principal Component Analysis (PCA) with the statistical package SAS (SAS 1995, Catling 1990).

The results show that the presence of calaveritas in the community, depends on the interrelations among; the presence of the backyard or solar structure, the woman's role and the use value as predominant form of assessment among the inhabitants of the Chilapa region. The traditional backyard or solar are spaces bordering to the house where it keeps a great diversity of vegetal and animal resources destined for family self-consumption. Since pre-hispanic times these sites have worked as storage and transmission centers of traditions, customs and values that determine the traditional life form that prevails in the Chilapa region; through the family at a first instance and specially through the woman. The feminine performance is fundamental in the execution of the management practices and the values that maintain and conserve the calaverita, since in the women resides the possession of the knowledge and its transmission. The transmission process is made by two ways; the first way from mother to daughter. The mother, who is in charge of all the activities that are made in the backyard or solar, teaches to its daughters and involves them with the practices, particularly with those related to the religious and 


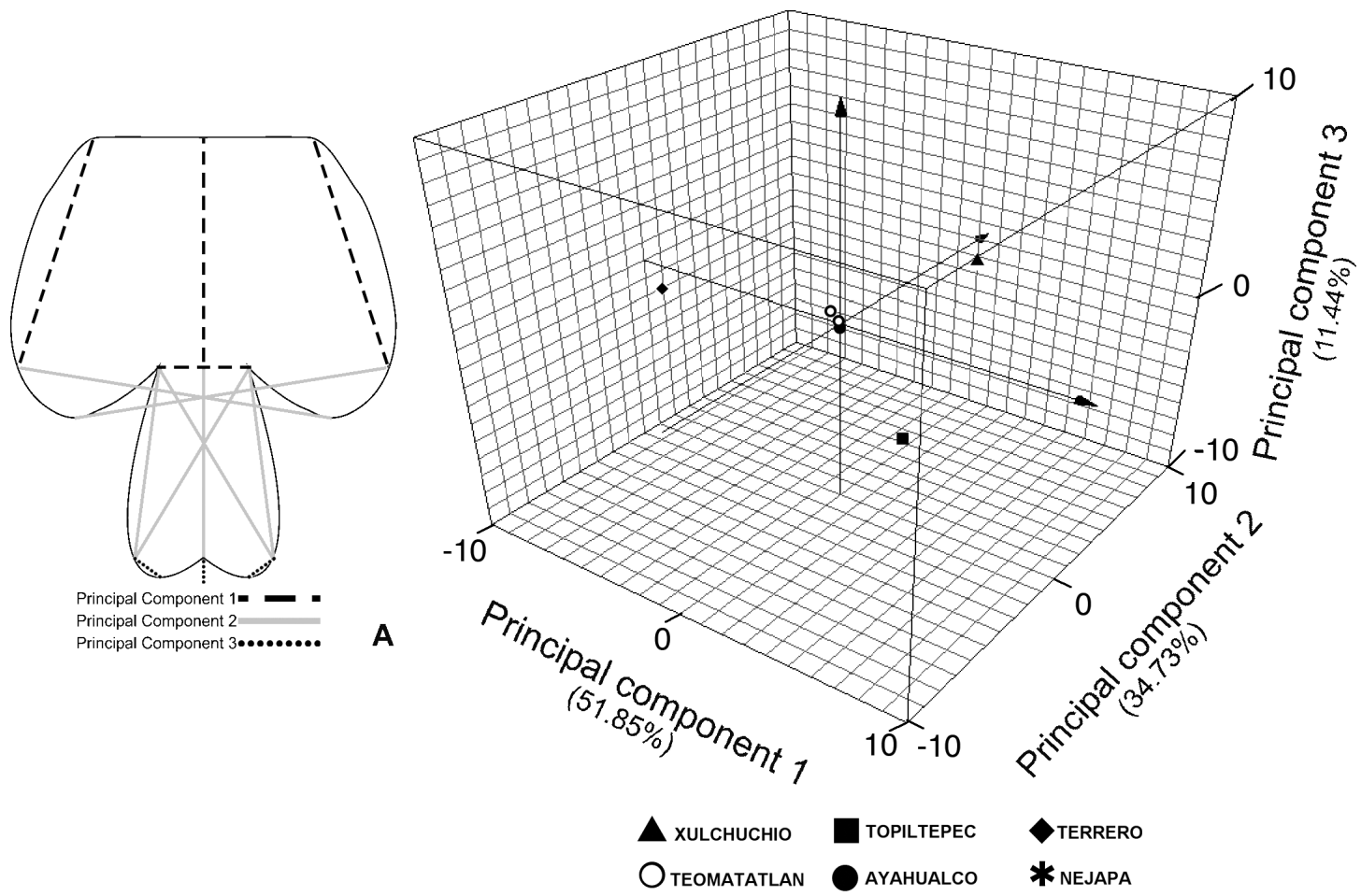

Figure 1. Principal Component Análisis Diagram for the lip variation of L. anceps subsp. dawsonii f. chilapensis. A) lip outline showing three principal componentes used in analysis of lip that explain the $98 \%$ of the variation.

aesthetic scope in which is inserted the care of the calaveritas. Later when one of its daughters get marriage, the mother inherits to her daughter a cutting of "calaveritas" that will take to its new house and with that will be able to continue with her familiar customs.

The other way of transmission, from mother-in-law to daughter-in-law, is carried out when a woman gets marriage and is gotten to live to mother-in-law's house. In this situation the wife (daughter-in-law) learns the traditions, values and practices that are made in the backyard or solar, from their mother-inlaw and when she dies, she will be in charge of the backyard or solar, the calaveritas and the continue of the traditions.

It is convenient to indicate that in some cases both situations appear where a woman inherits by the two routes the knowledge and the calaveritas. In opinion of Chilapa women, the knowledge transmission from mother to daughter has greater probability of finalize, since the case of transmission of mother-in-law to daughter-in-law, not always occurs or wether it occurs, is in bad terms because in many cases, the daughters-in-law come from other villages, communities or other states from the country with different customs and practices. On the other hand it is perceived into the community that the current gender role changes, that is to say, the distance of the young woman from the rural life and its incorporation to the labor and urban life, represents a threat for the future transmission of the practices that have allowed the existence of the calaveritas.

Another element recognized as part of the traditional use system, is the valuation factor exists around the calaverita. Into the community predominates the use value or self-comsumption as the main valuation form, which is considered or assigned by the user of the goods from the satisfaction it provides for some of its necessities. For the calaverita, it was verified that this one satisfies spiritual and ornamental aspects that reside in the necessity to honor, to remember and to celebrate the faithfuls deads through the festivity of the day of deads, fundamental activity in the Mexican idiosyncrasy that has worked as incentive in the conservation of the chilapensis form. 
Finally within the chilapensis form specimens lodged in the backyards of Chilapa Guerrero, it was found morphological lip variation. The Principal Component Analysis showed that the first three Principal Components (PC) explained 98\% of the variation. The first PC explained $52 \%$ and corresponded mainly to the variables related with the size of the mid lobe (long and wide) and to the lateral lobes width. The second PC explained $34 \%$ and it's basically defined by the height of the lateral lobes and the wide one of the base of the mid lobe, whereas the third CP explained $12 \%$ of the variation, represented by the height of the apical lobes of the mid lobe. The PCA shows the distribution of four groups within the form chilapensis (fig 1). The first group integrated by specimens from the localities of Nejapa, Ayahualco and Teomatatlán, includes plants with quadrangular mid lobe form, with similar wide and length dimensions, in its apical part barely presents 2 formed lobes. The lateral lobes had the highest means values with respect to the rest of the units. The second group is represented by specimens from Topiltepec, it includes plants with piramidal mid lobe, long, thin in the base and wide towards the apex with 2 apicales lobes barely formed. The third group conformed by specimens from Xulchuchio, characterized itself to display a piramidal mid lobe, long, wide in base and towards the apex with 2 strongly pronouncing apicales lobes. And the fourth group represented by specimens from the locality of El Terrero, which was characterized to display a rectangular form mid lobe, narrow and short, in its apical part presents a single lobe.

Under the previous context, it concludes that in the region of Chilapa Guerrero is conserved more than one phenotype of the chilapensis form. In the region it is preserved not only one of the more showiest, elegant and attractive forms of the genus Laelia in Mexico, but it is also protected the knowledge, traditions and values that gives sustenance to the traditional forms of genetic resources possession. The traditional use of Laelia has allowed the conservation of the specie and its variation.

AKNOWLEdGEMENTS. Special thanks to Miguel Angel Soto Arenas for his valuable comments and support.

\section{LITERATURE CITED}

Catling, P.M. 1990. Malaxis salazarii, a new species from Mexico and northern Mesoamerica. Orquidea (Méx.) 12(1):93-104.

De Garay, G. 1994. La Historia con micrófono. Instituto Mora. México.

Davis, S.D., V.H. Heywood \& A.C. Hamilton (eds.) 1994. Centers of Plant Diversity. A Guide and Strategy for their Conservation. Vol. 3. The Americas. World Wide Fund For Nature (WWF) and the World Conservation Union (IUCN). Publications Union Cambridge, UK. $562 \mathrm{p}$.

Halbinger, F. \& M.A. Soto. 1997. Laelias of México. Orquídea (Méx.) Vol. 15. Asociación Mexicana de Orquideologia, A.C. México D. F. México.

Miranda, T. J. 2005. Conocimiento Campesino en el Manejo de la Diversidad de Haba (Vicica faba) en los Llanos de Serdán, Puebla. Tesis de Maestría, Colegio de Postgraduados Campus Puebla. México. pp.144

SAS Institute. 1995 SAS/STAT User's guide, version 6, fiveth edition, volume 1 and 2. SAS Institute Inc. Cary, N. C.

Toledo, V. 1991. El Juego de la Supervivencia: Un Manual para la investigación etnoecológica en Latinoamérica. Consorcio Latinoamericano de Agroecología y desarrollo (CLADES), Santiago de Chile, Berkeley, USA. pp. 75.

Victor Manuel Salazar-Rojas is student of the Strategies for Rural Development Program at the Colegio de Postgraduados-Campus Puebla in México, He is particular interested on the relation among orchids, traditional kwnowledge, conservation and rural development.

Edgar Herrera-Cabrera is professor at the Colegio de Postgraduados-Campus Puebla in México, specialized in genetic improvement and he imparts a course of genetic resource and diversity. He works in basic crop in traditional agroecosystem, in particular he is interested in the use, diversity and conservation of the orchids of Mexico (Laelia and Vanilla). He belongs to the national research system. 